\section{Memories of the workhouse}

\author{
John Launer
}

I trained as a doctor at the Middlesex Hospital, close to the centre of London. When it was built in the eighteenth century, the Middlesex was on the very edge of the city, in open fields, but London swallowed it up and then extended a huge distance beyond. The hospital found itself close to the capital's main shopping streets and private medical consulting rooms. It became a leading national centre for patient care and for training. Then history had some more tricks to play. In the 1980s, all the medical schools in London were reorganised, and it was merged with the hospital at University College London (UCL) - originally founded because the Middlesex had refused to allow UCL students onto its wards. It was then demolished to make way for a massive commercial development of shops and expensive apartments. Only the listed chapel - a fantastical gothic creation from the 1920s, with a marble interior and mosaics - has been left intact.

Some of my memories of training at the Middlesex are good, but others are not. Among the most uncomfortable ones are from the out-patient clinics. These took place not in the main hospital but in a drab brick building a hundred metres further north, in Cleveland Street. Patients sat massed together, all waiting in one large hall. The doctors sat at desks at the front of the hall, and saw each patient in full sight of everyone, and within earshot of the front rows. There was a distinctly 'poor law' feel about the place, as if patients should be grateful to be seen at all, even if their suffering was a public spectacle. Some of the doctors - although not all - had attitudes that reflected this. Once, in a side room off the main hall, I witnessed the most horrible consultation I can remember. In front of at least a dozen medical students, a famous surgeon broke the news to a middle aged man that his cancer would require removal of half his face. With an ineptness that makes me wince to this day, he stuttered out a ghastly mixture of hints, euphemisms and evasions that forced the man to confront him, in order to elicit the full horror of his disease. If I could have chosen one word to

Correspondence to Dr John Launer, Faculty Development, Health Education England, Stewart House, 32 Russell, London WC1B 5DN, UK: john.launer@nwl.hee.nhs.uk describe both the place and its proceedings, I probably would have used the word Dickensian. Strangely enough, the word would have been entirely apt.

\section{ATROCIOUS CONDITIONS}

Like many hospital buildings in London, the out-patient department had once been a workhouse. ${ }^{1}$ It was built around the same time as the Middlesex itself, in order to accommodate destitute parishioners from nearby Covent Garden. It expanded after the New Poor Law came into force in 1834 , bringing in atrocious conditions of near-starvation and forced labour for the inmates. It carried on as a workhouse until the Middlesex purchased the building early in the twentieth century. However, no-one realised until very recently that this was no ordinary workhouse. It was the one that Charles Dickens drew on for his best-known masterpiece, 'Oliver Twist'.

When Dickens wrote his novel, he never identified the exact institution he had in mind. Historians knew he had lived in this part of London in his early childhood, in somewhere called Norfolk Street. He had also returned there in his late teens. By the twentieth century, no street with that name existed, so no-one imagined that Norfolk Street was anywhere near Cleveland Street, or that Dickens might have been familiar with its workhouse. It was only in 2010, when the Middlesex Hospital had already been destroyed and the out-patient building was sentenced to the same fate, that local people started to look for a connection that might justify an appeal. They approached the historian Dr Ruth Richardson and asked if she could find something - anything - that might serve as evidence. With four weeks to go before the local council was due to make its final decision about demolition, Richardson pored over old maps of London. She then made a discovery so exciting that it made her 'yelp out loud with delight'. ${ }^{2}$ Norfolk Street wasn't simply nearby: it was the old name for the southern part of Cleveland Street, abutting the Middlesex Hospital. The young Charles Dickens and his family had lived nine doors away from the workhouse gates! Once Richardson had established that this was almost certainly the model for the workhouse in Oliver Twist, it was put on the list of protected buildings. - although a battle is still being fought over other parts of the site, including the Master's House, two receiving wards, some old Nightingale wards at the back, and the workhouse burial grounds. They are now under threat of being lost beneath a tower block.

\section{FORMATIVE YEARS}

Following her discovery, Richardson published a book on Dickens, the workhouse, and the London poor. ${ }^{3}$ It brings the novelist and his times vividly to life. Dickens spent the formative years of his childhood walking past the portal of the Cleveland Street workhouse, with its stone relief exhorting passers-by to 'Avoid Idleness and Intemperance', in order to avoid incarceration within. Later on, as a factory-boy in Covent Garden, he worked alongside young lads who would have been nighttime inmates of the institution, farmed out as unpaid labour during the day. He may have heard from them how appalling life was there, with its notorious diet of thin gruel, reduced further during periods of punishment. When the Dickens family descended into penury, as they sometimes did, young Charles may well have been afraid that they would all end up there, with his parents separated from the children, and the siblings from each other, according to the regulations. Dickens may also have heard of other atrocities associated with the place. Just a few years before his family had moved to the area, a woman in labour was refused admission to the workhouse. She gave birth to her baby in the street outside. When the child died, the local people broke down the doors and carried the grieving mother into one of the workhouse wards.

In later life, Dickens became a passionate supporter of workhouse improvement. In 1866 , he sent a donation to the great reforming doctor Joseph Rogers, physician to the Cleveland Street workhouse. Along with the donation, Dickens sent a note, pointing out that it was no wonder that 'the poor should creep into corners to die rather than fester and rot in such infamous places'. ${ }^{4}$ Rogers had already put his career on the line by protesting directly to Whitehall about the policy of putting women on a starvation diet for nine days after childbirth, to discourage others coming there for confinement. He was later forced to resign as a whistle-blower, having exposed serious neglect at the workhouse. ${ }^{5}$ His campaigning efforts, along with the backing of eminent people like Dickens, Florence Nightingale and the editor of 'The Lancet', Thomas Wakley, eventually led to the alleviation of conditions in the workhouses, and finally their abolition. 


\section{On reflection}

I cherish no nostalgia for the Cleveland Street workhouse building, or for what I saw there when it was part of the Middlesex, but I am glad it has been saved for posterity. It is a necessary reminder of the many different forms of cruelty that took place there, and in similar institutions, and especially of the people who stood up against such cruelty.

Twitter Follow John Launer at @JohnLauner
2 Richardson R. At the workhouse on Cleveland Street. Spitalfields Life, 12 Oct 2013. http://spitalfieldslife. com/2013/10/12/at-the-workhouse-on-cleveland-st (accessed 25 Mar 2015).

3 Richardson R. Dickens and the Workhouse: Oliver Twist and the London Poor. Oxford: Oxford University Press, 2012.

To cite Launer J. Postgrad Med J 2015;91:299-300.

Postgrad Med I 2015;91:299-300.

doi:10.1136/postgradmedj-2015-133436

\section{REFERENCES}

1 The workhouse in Strand, London: Middlesex. http:// www.workhouses.org.uk/Strand/ (accessed $25 \mathrm{Mar}$ 2015). 